\title{
HEAT TRANSFER ENHANCEMENT AND FRICTION FACTOR ANALYSIS IN TUBE USING CONICAL SPRING INSERT
}

\author{
Rahul M. Gupta ${ }^{1}$, Bhushan C. Bissa ${ }^{2}$ \\ ${ }^{I}$ Research Scholar, Department of Mechanical Engineering, Shri Ramdeobaba College of Engg And Mgmt, Nagpur, \\ Maharashtra, India \\ ${ }^{2}$ Assistant Professor, Department of Mechanical Engineering, Shri Ramdeobaba College of Engg And Mgmt, Nagpur, \\ Maharashtra, India
}

\begin{abstract}
Role of the conical spring array for the heat transfer enhancement and pressure drop change in a pipe with constant heat flux boundary condition was investigated. Three different arrangements of conical spring array inserts were used in the experimental setup. Conical spring inserts with diverging conical spring, converging-diverging conical spring and converging conical spring array inserts arrangements were used. Water was used as a working fluid in the experimental setup. It was found that use of conical spring array inserts arrangement leads to enhancement in heat transfer. Higher heat transfer rate was achieved in the divergent spring array arrangement than the converging-diverging and converging arrangement. However, maximum friction factor is achieved in the diverging spring array insert arrangement. By increasing the Reynolds Number for different turbulator arrangement, the significant increase in Nusselt number was obtained. The enhancement in Nusselt Number for the diverging, converging-diverging, converging conical spring array arrangement was $645 \%, 431 \%$ and $259 \%$ respectively. The heat transfer enhancement efficiency can be evaluated based on the power consumption per unit mass of fluid. Heat transfer enhancement efficiencies were found for the divergent spring array arrangement up to $277 \%$ and for the convergent-divergent spring arrangement up to $212 \%$ and for the convergent spring array arrangement up to $153 \%$.
\end{abstract}

Keywords- Heat exchanger, Heat transfer enhancement, Friction factor, Conical spring turbulator, Heat transfer enhancement efficiency.

\section{INTRODUCTION}

Heat transfer is a discipline of thermal engineering that concerns the generation, use, conversion, and exchange of thermal energy and heat between physical systems. Various heat transfer mechanisms can be classified such as thermal conduction, thermal convection, thermal radiation, and by phase change process. Differing chemical species, either cold or hot, also considered to achieve heat transfer. They often occur simultaneously in the same system, while these mechanisms have distinct characteristics,

Lot of techniques have been used to improve the performance of heat exchanging devices for reducing material cost and surface area and decreasing the difference for heat transfer thereby for reducing external irreversibility. Various types of inserts are promising among different passive means to increase heat transfer coefficient. Greater mixing and higher heat transfer coefficients are promoted by the secondary flow (swirl flow) generated by inserts effects fluid flow across inserts-partitioned tube.

In areas such as process industries, heating and cooling in evaporators, thermal power plants, air-conditioning equipment, refrigerators, radiators for space vehicles, automobiles, etc. heat transfer augmentation techniques (passive, active and compound) are commonly used. Compared with active techniques, passive techniques, where inserts are used in the flow passage to augment the heat transfer rate, are advantageous, because the insert manufacturing process is simple and these techniques can be easily applied in an existing application. Several studies on the passive techniques of heat transfer augmentation have been reported in the past decade. The most commonly used passive heat transfer augmentation tools are twisted tapes, wire coils, ribs, fins, helical coil etc.. Bodius Salam et al. [1] experimentally investigated turbulent flow in a circular tube fitted with rectangular-cut twisted tape insert, for measuring heat transfer enhancement efficiency of water, friction factor and tube-side heat transfer coefficient. He found that with increase of Reynolds Number, the Nusselt Number increases. P. Promvonge [2] experimentally investigated the heat transfer rate and friction factor of the conical ring turbulator inserts.He found that higher heat transfer are achieved for the conical ring inserts than that of the plain tube surface. However, the increase in friction factor is much higher than that in Nusselt number at the same Reynolds number. With the decrease in diameter ratio for a fixed Reynolds number, both the Nusselt number and friction factor increases. Durmus [3] studied a heat exchanger tube at constant outer surface temperature with cut out conical turbulators, on the heat transfer rates was investigated. He found that from the heat transfer point of view the conical turbulators are relatively favorable. Promvonge and Eiamsaard [4] studied the heat transfer and friction characteristics in a circular tube having conical- 
nozzle turbulator inserts. He found that the significant increase in Nusselt number was obtained by increasing the Reynolds number at a various pitch ratio, $\mathrm{PR}=2,4$ and 7 of the turbulators. However, with the reduction of pitch ratio and Reynolds number, the friction factor at a given Reynolds number considerably increases. Promvonge and Eiamsaard [5] experimentally investigated the heat transfer enhancements characteristics of conical nozzles and swirl generator in a uniform heat flux circular tube. A.R. Anvari et al. [6] experimentally studied forced convective of water in horizontal tubes with conical tube inserts. He found that enhancement of heat transfer occurred by the insertion of turbulators. A.R. Anvari et al. [7] experimentally investigated with CFD predictions of the heat transfer enhancement and pressure drop change in a pipe by using conical ring arrangements. He found that the enhancement efficiency have unfavorable effect by using the conical ring inserts. P. Bharadwaj et al., [8] experimentally investigated heat transfer and pressure drop characteristics of flow of water for Laminar to fully turbulent ranges with twisted tape insert in a spirally grooved tube. He concluded that maximum enhancement in the laminar range was obtained than the turbulent range for spirally grooved tube with twisted tape insert. Haydar Eren et al. [9] experimentally studied the heat transfer behavior of circular coil-spring tabulators. He concluded that heat transfer increases by spring number, spring diameter, and incline angle. Yakut et al. [10] Experimentally investigated by means of the entropy-generation minimization method based on the second law and enhancement efficiency based on the first law of thermodynamics, the performance characteristics of the conical-ring turbulators were determined. By using the augmentation entropy-generation number and the heattransfer enhancement efficiency as performance criteria the thermal performances of conical-ring turbulators inserted in an aluminum smooth tube were determined with respect to heat transfer and flow-induced vibration characteristics. Yakut and Sahin [11] experimentally investigated flowinduced vibration characteristics of conical-ring turbulators used for heat transfer enhancement in heat exchangers. It is found that the the maximum heat transfer is obtained for the smallest pitch arrangement and Nusselt Number increases with the increasing Reynolds Number and the maximum heat transfer is obtained for the smallest pitch arrangement.

The objective of this project work is to analyze the heat transfer enhancement and friction factor for conical springs placed in three different arrangements: converging conical spring converging-diverging conical spring and diverging conical spring for different Reynolds Number.

\section{EXPERIMENTAL DESCRIPTION}

\subsection{Experimental Set Up}

Fig 1. Shows the schematic diagram of the experimental setup. The smooth tube and tube with conical spring insert was used in the experimental set up. The tube material used was copper. The length of the tube used was $1 \mathrm{~m}$ and tube diameter was $22.22 \mathrm{~mm}$ in $1 \mathrm{~mm}$ thickness. In this experiment water was used as a working fluid. Fluid was flowing in only one direction. Rotameter was used for measuring the flow rate of water. The range of Rotameter was 0-25 liter per minute (LPM). Thermocouples were used for measuring temperature at the inlet and outlet of tubes. The uniform heat flux wire type heater was fabricated from nichrome wire.

\begin{tabular}{|c|c|}
\hline \multicolumn{2}{|c|}{ NOMENCLATURES } \\
\hline A & Heat transfer surface area $\left(\mathrm{m}^{2}\right)$ \\
\hline$A_{f}$ & Flow area $\left(\mathrm{m}^{2}\right)$ \\
\hline $\mathrm{C}_{\mathrm{p}}$ & Specific heat of water at constant pressure $(\mathrm{J} / \mathrm{kg}-\mathrm{K})$ \\
\hline $\mathrm{D}$ & Tube diameter $(\mathrm{m})$ \\
\hline $\mathrm{f}$ & Friction factor \\
\hline $\mathrm{f}_{\mathrm{th}}$ & Theoretical friction factor \\
\hline $\mathrm{g}$ & Gravitational acceleration $\left(\mathrm{m} / \mathrm{s}^{2}\right)$ \\
\hline $\mathrm{h}$ & Heat transfer coefficient $\left(\mathrm{W} / \mathrm{m}^{2}-\mathrm{K}\right)$ \\
\hline $\mathrm{H}$ & Manometer Reading (m) \\
\hline $\mathrm{h}$ & Experimental heat transfer coefficient $\left(\mathrm{W} / \mathrm{m}^{2}-\mathrm{K}\right)$ \\
\hline $\mathrm{h}_{\mathrm{th}}$ & $\begin{array}{l}\text { Heat transfer coefficient from Petukhov, } 1970 \\
\left(\mathrm{~W} / \mathrm{m}^{2}-\mathrm{K}\right)\end{array}$ \\
\hline $\mathrm{k}$ & Thermal conductivity of water $(\mathrm{W} / \mathrm{m}-\mathrm{K})$ \\
\hline $\mathrm{L}$ & Length of the test tube $(\mathrm{m})$ \\
\hline $\mathrm{m}$ & Mass flow rate of water $(\mathrm{kg} / \mathrm{s})$ \\
\hline $\mathrm{Nu}$ & Nusselt number \\
\hline $\mathrm{Nu}_{\mathrm{th}}$ & Nusselt number from Gnielinski, 1976 correlation \\
\hline $\operatorname{Pr}$ & Prandtl number \\
\hline Q & Heat transfer rate $(\mathrm{W})$ \\
\hline $\mathrm{q}$ & Heat flux $\left(\mathrm{W} / \mathrm{m}^{2}\right)$ \\
\hline $\operatorname{Re}$ & Reynolds number \\
\hline $\mathrm{Re}_{\mathrm{th}}$ & Theoretical reynolds number \\
\hline $\mathrm{T}$ & Temperature $\left({ }^{\circ} \mathrm{C}\right)$ \\
\hline $\mathrm{U}_{\mathrm{m}}$ & Theoretical mean velocity $(\mathrm{m} / \mathrm{s})$ \\
\hline $\mathrm{V}$ & Mean velocity $(\mathrm{m} / \mathrm{s})$ \\
\hline$\Delta \mathrm{P}$ & Pressure drop $\left(\mathrm{N} / \mathrm{m}^{2}\right)$ \\
\hline \multicolumn{2}{|c|}{ Greek symbols } \\
\hline$\rho$ & Density of water $\left(\mathrm{kg} / \mathrm{m}^{3}\right)$ \\
\hline$\mu$ & Dynamic viscosity of water $(\mathrm{kg} / \mathrm{m}-\mathrm{s})$ \\
\hline$\eta$ & Heat transfer enhancement efficiency \\
\hline \multicolumn{2}{|c|}{ Subscripts } \\
\hline $\mathrm{b}$ & Bulk \\
\hline in & Inlet \\
\hline out & Outlet \\
\hline $\mathrm{p}$ & Plane tube \\
\hline $\mathrm{pp}$ & Constant pumping power \\
\hline $\mathrm{t}$ & Turbulator \\
\hline w & Surface \\
\hline
\end{tabular}

This wire was connected in series with dimmer stat in order to supply the same amount of heat to nichrome wire. The heat was provided on $1 \mathrm{~m}$ length of tube and the other side was unheated as well as insulated. Commercial glass wool insulation was used on the external surface to prevent the heat leakage due to convection and radiation. The heated test section was $1000 \mathrm{~mm}$ long. For wall temperature measurement, four thermocouples were used at different place of heating surface. Moreover, one thermocouple was 
placed at the inlet and one thermocouple was placed at outlet to measure the inlet and outlet bulk temperatures, respectively. Manometer was used to measure the pressure drop within the tested tube. The mass flow rate of water was controlled with the help of bypass control valve. The bypass control valve was used to control the mass flow rate of water by adjusting the valve knob position. Readings were taken at the various mass flow rate of water.

\subsection{Experimental Procedure}

In the apparatus setting below in fig 1. the water tank was filled using the water at ambient condition and then the water pump was started. The current and voltage in ammeter and voltmeter were set so that it gave the uniform heat flux to the tube at the wall temperature range of $36^{\circ} \mathrm{C}$ to $37^{\circ} \mathrm{C}$. And then by setting the flow rate of the working fluid at 3,4,5,6,7,8,9 and 10 LPM in each run. The setup was run continuously till the steady state was achieved. After achieving the steady states the reading of temperature for a specified flow rate at the inlet and outlet of tube without using any inserts i.e. for smooth tube were taken. And also the reading of tube surface temperatures at four locations by using a digital temperature controller was taken. The reading of pressure drop across the test tube section was taken by using the U-tube manometer. The experiment was repeated with setting different valve positions of the bye pass valve for different flow rate. The same experimental procedure is repeated for different inserts inside the smooth tube which were as follows: In each test run, the conical springs were placed in three type arrays: (1) diverging conical spring array, (2) converging-diverging conical spring array and (3) converging conical spring array respectively.

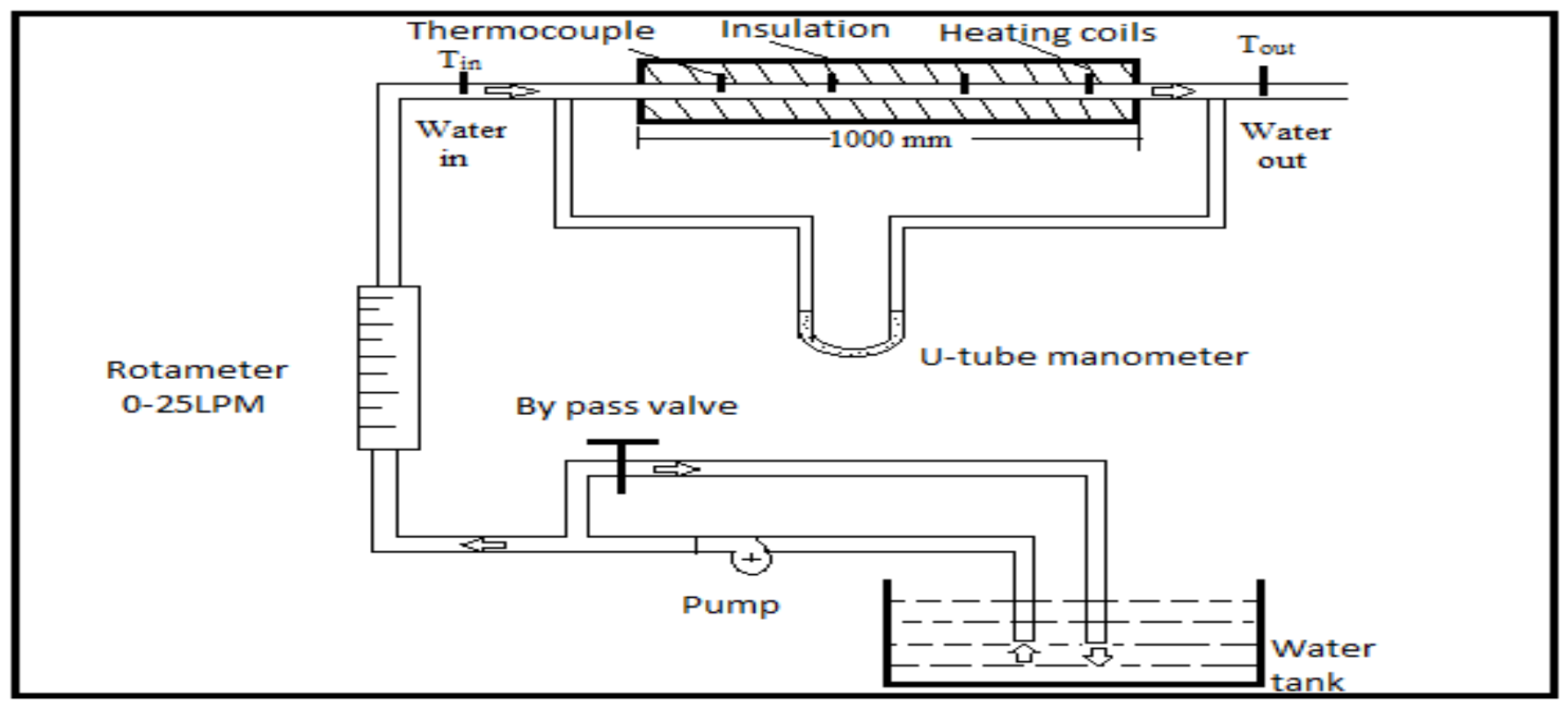

Fig 1 Schematic diagram of experimental apparatus

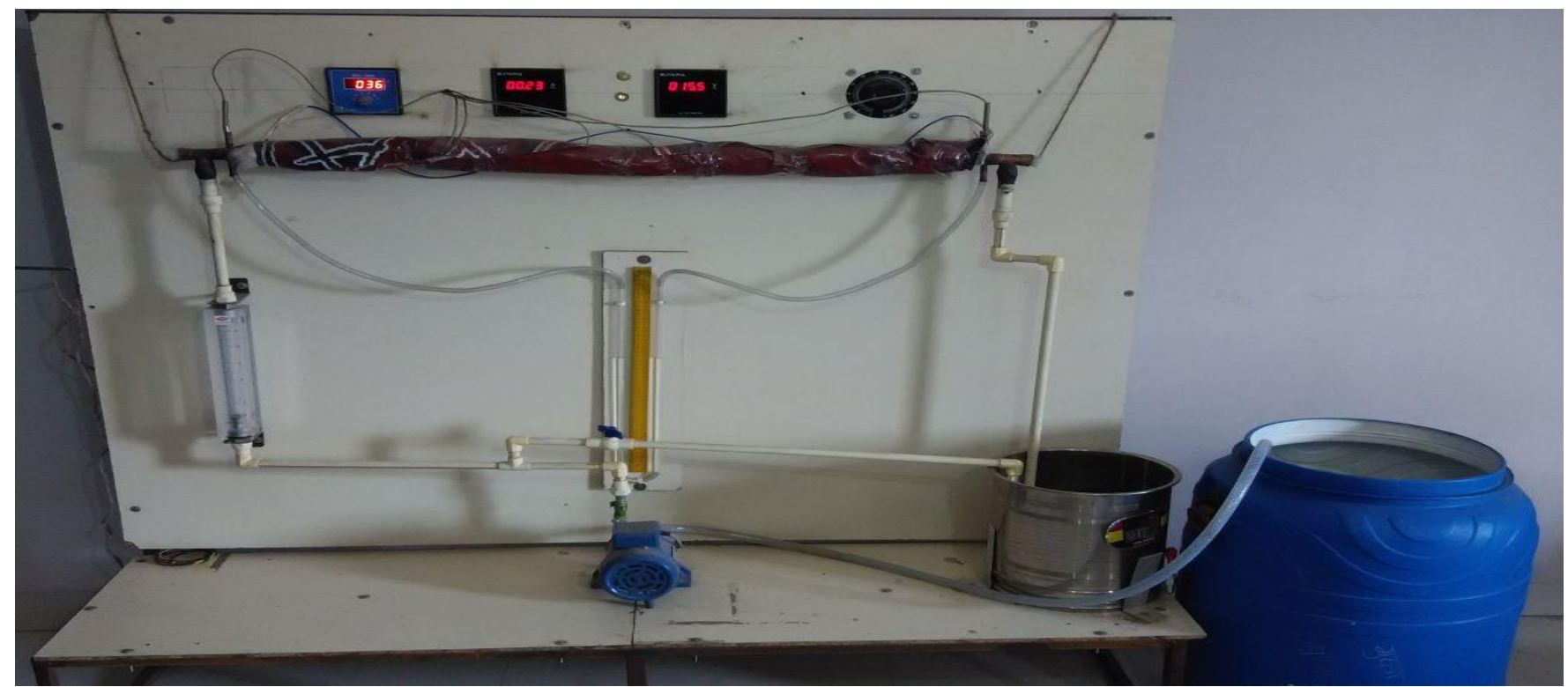

Fig 2 Experimental setup 


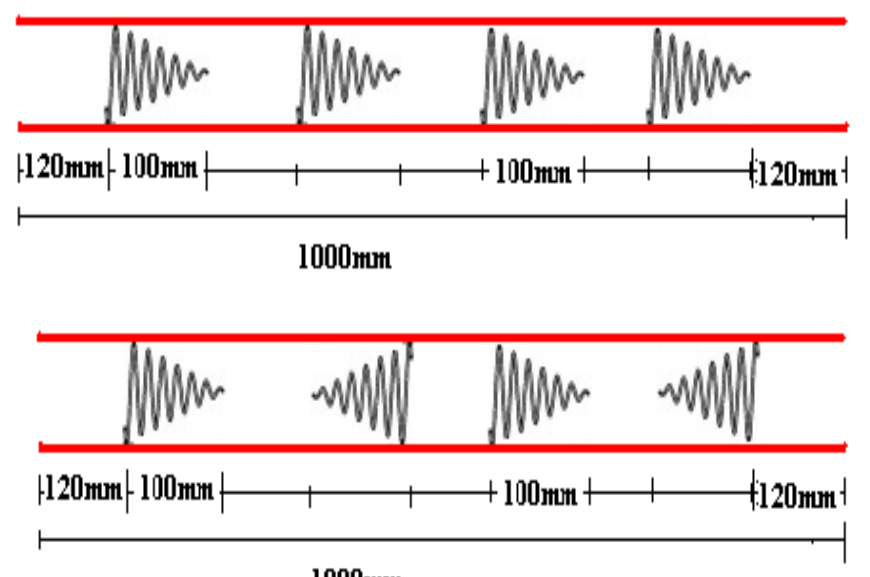

1000 mum

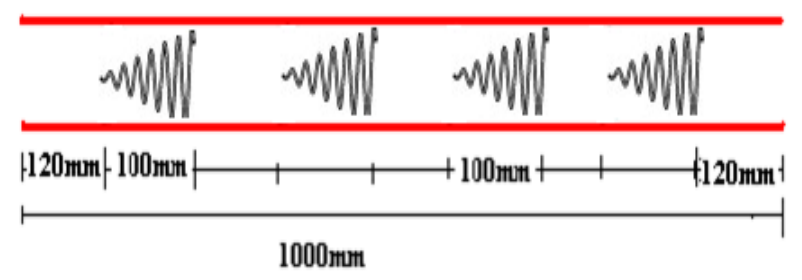

Fig 3 various conical spring arrays arrangements in the test tube, (a) Diveregent conical spring array, (b) Convergentdivergent conical spring array and (c) Convergent conical spring array

\section{GEOMETRY OF CONICAL SPRING INSERT}

Aluminium material ribs were used for experimental purpose due to easily availability and can be easily bent in required shape and angle as well as it is light in weight. For experimentation purpose four conical spring inserts were manufacture at same length and same diameter. 4 conical spring inserts were taken at experiment purpose at different arrangements and their performance was compared.

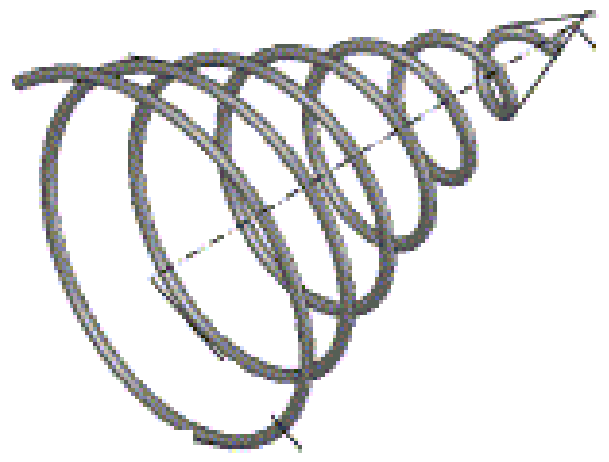

Fig 4 Schematic diagram of conical Spring Insert

$>$ Maximum diameter $\left(\mathrm{D}_{\max }\right)=22.22 \mathrm{~mm}$

$>$ Minimum diameter $\left(\mathrm{D}_{\min }\right)=20.22 \mathrm{~mm}$

$>$ Diameter of wire $(\mathrm{d})=2 \mathrm{~mm}$

$>$ Material $=$ Aluminium

$>$ Length of spring $=100 \mathrm{~mm}$

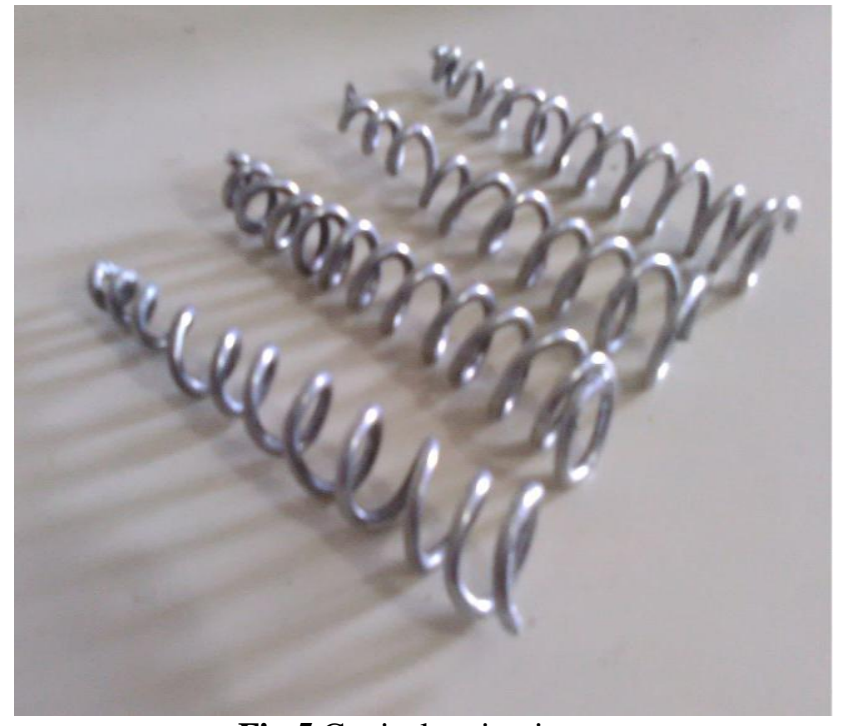

Fig 5 Conical spring insert

\section{DATA REDUCTION}

Heat transfer rate by the heater to water was calculated by measuring heat added to the water. Heat added to water was calculated by,

$$
\mathrm{Q}=\mathrm{m} \times \mathrm{C}_{\mathrm{p}} \mathrm{x}\left(\mathrm{T}_{\text {out }}-\mathrm{T}_{\text {in }}\right)
$$

The bulk temperature was obtained from the average of water inlet and outlet temperatures,

$$
\mathrm{T}_{\mathrm{b}}=\left(\mathrm{T}_{\mathrm{in}}+\mathrm{T}_{\text {out })} / 2\right.
$$

where all of the thermo physical properties of the water were determined at the overall bulk water temperature from Eq. (2).

Tube surface temperature was calculated from the average of four local tube outer surface temperatures,

$$
\mathrm{T}_{\mathrm{w}}=\sum \mathrm{T}_{\mathrm{w}} / 4
$$

Experimental Heat transfer coefficient was calculated from,

$$
\mathrm{h}=\mathrm{Q} / \mathrm{A} \times\left(\mathrm{T}_{\mathrm{w}}-\left(\mathrm{T}_{\text {in }}+\mathrm{T}_{\text {out }}\right) / 2\right)
$$

The average Nusselt number was calculated by,

$$
\mathrm{Nu}=\mathrm{h} \times \mathrm{D} / \mathrm{k}
$$

The Reynolds number was calculated by,

$$
\operatorname{Re}=(\rho \times \mathrm{D} \times \mathrm{V}) / \mu
$$

The pressure drop was calculated by,

$$
(\Delta \mathrm{P})=\rho \times g \times H
$$

where $\mathrm{g}$ is gravitational acceleration which is equal to 9.81 $\mathrm{m} / \mathrm{s}^{2}$ 
The friction factor $\mathrm{f}$ was calculated by,

$$
\mathrm{f}=\Delta \mathrm{P} \times 2 \times \mathrm{D} / \mathrm{L} \times \rho \times \mathrm{V}^{2}
$$

where $\mathrm{V}$ is the mean water velocity in the tube.

Theoretical Nusselt number was calculated from Gnielinski, 1976, correlation,

$$
\mathrm{Nu}_{\mathrm{th}}=\left(\mathrm{f}_{\mathrm{th}} / 8\right) \mathrm{x}\left(\operatorname{Re}_{\mathrm{th}}-1000\right) \mathrm{x} \operatorname{Pr} / 1+12.7\left(\mathrm{f}_{\mathrm{th}} / 8\right)^{1 / 2}\left(\operatorname{Pr}^{2 / 3}-1\right)
$$

Theoretical Friction factor, f can be calculated from Petukhov, 1970,

$f=\left(0.79 \times \ln \operatorname{Re}_{t h}-1.64\right)^{-2}$

$\mathrm{Re}_{\mathrm{th}}=\left(\rho \times \mathrm{D} \times \mathrm{U}_{\mathrm{m}}\right) / \mu$

$\mathrm{P}_{\mathrm{r}}=\left(\mu \times \mathrm{C}_{\mathrm{p}}\right) / \mathrm{k}$

$\left(\mathrm{Nu}_{\text {th }}=\mathrm{h}_{\mathrm{th}} \mathrm{x} \mathrm{D} / \mathrm{k}\right.$

Theoretical mean water velocity was obtained from,

$$
\mathrm{U}_{\mathrm{m}}=\mathrm{m} / \mathrm{A}_{\mathrm{f}}
$$

Flow area was obtained from,

$$
\mathrm{A}_{\mathrm{f}}=\pi / 4 \times \mathrm{D}^{2}
$$

\section{RESULTS AND DISCUSSION}

In this section the results obtained during the experimental investigation are discussed and presented. The results are proposed in terms of Nusselt number $(\mathrm{Nu})$ and friction factor ( $f$ ) for the experimental investigation of the heat transfer and the friction factor characteristics in a uniform heat flux tube fitted with conical spring turbulators of three different types of arrays divergent, convergent-divergent and convergent conical spring insert.

\subsection{Verification of the Plain Tube}

Previous correlations from the open literature [14] under similar conditions are used for verification of heat transfer and friction factor correlations of the plain tube. Gnielinski and Petukhov [14] correlations are used for the verification of Nusselt number and the friction factor of the plain tube.

For the plain tube following empirical Nusselt number and friction factor correlations presented in Eqs. (16) and (17), respectively, are derived, representing the experimental data.

$$
\begin{aligned}
& \mathrm{Nu}=0.0520 \times \operatorname{Re}^{0.67} \operatorname{Pr}^{0.4} \\
& \mathrm{f}=56.5995 \times \operatorname{Re}^{-0.780}
\end{aligned}
$$

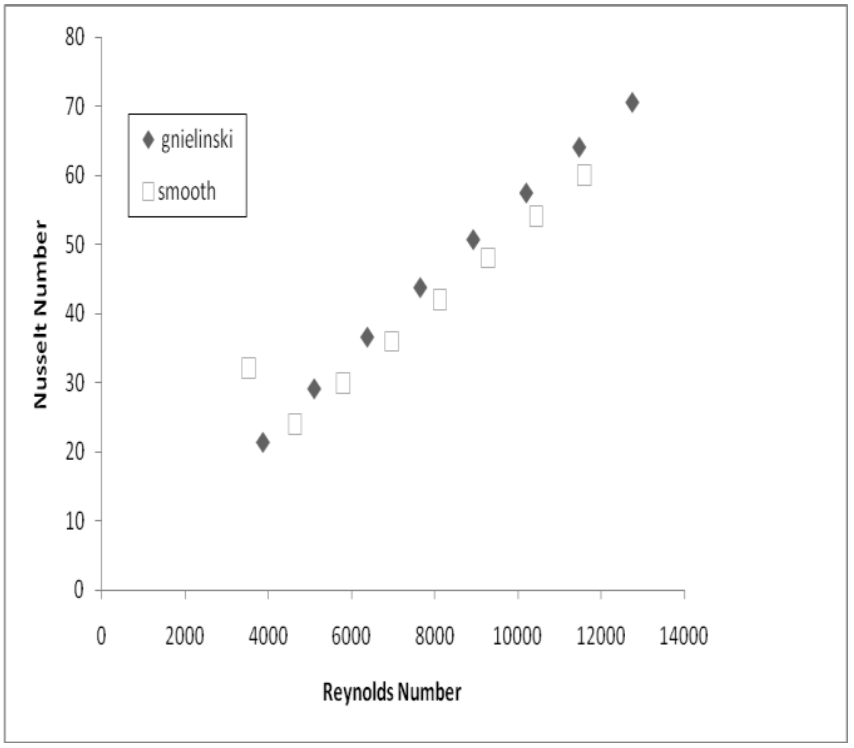

Fig 6 Verification of Nusselt number of plain tube

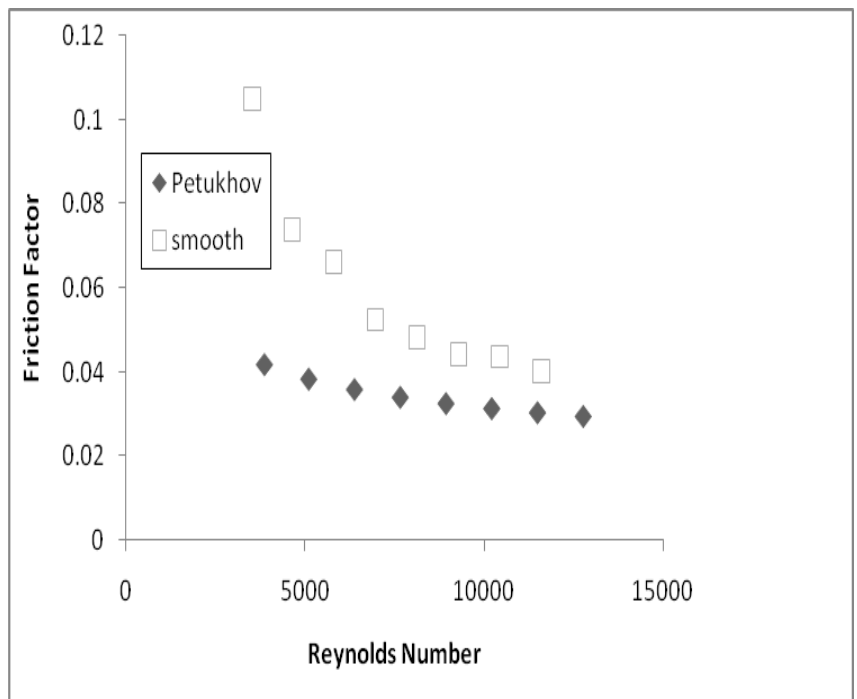

Fig 7 Verification of Friction factor of plain tube

\subsection{Effect of Conical Spring Arrangement}

Heat transfer coefficient and friction factor behavior for conical spring turbulator arrays are depicted in the figure. It is conclude that higher heat transfer rates are achieved for conical spring insert in tube than that of the plain tube. Greater mixing and higher heat transfer rates are promoted by the secondary flow (swirl flow) generated by conical spring inserts. Convection heat transfer is enhanced by the boundary layer disruption and reverse flow. Divergent spring array arrangement has better heat transfer than the convergent -divergent and convergent arrangement subsequently. However, the pressure drop obtained is maximum in the divergent spring array arrangement than the convergent-divergent and convergent arrangement. Hence, maximum friction factor is obtained for the divergent spring array arrangement. Divergent spring arrangement has better enhancement in the Nusselt Number than the other turbulators arrangement. For the particular spring arrangement the Nusselt Number enhances with increase of Reynolds Number i.e. with increase of flow rate. 


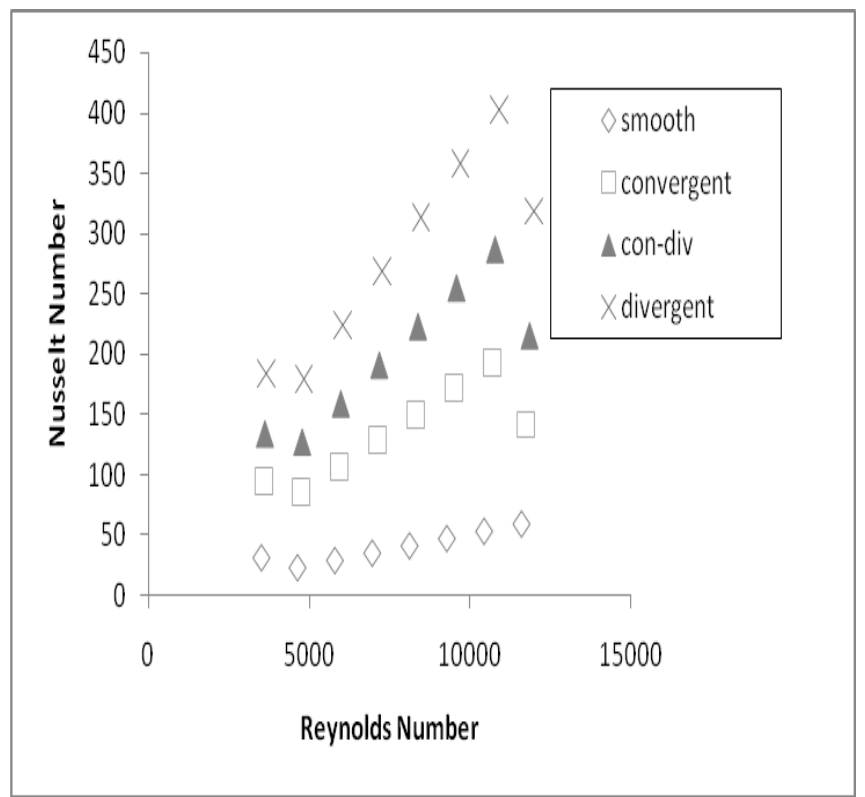

Fig 8 Variation of Nusselt number with Reynolds number for various turbulators

Nusselt number for the DS arrangement enhanced up to $645 \%$, and for the CDS arrangement up to $431 \%$ and for the CS arrangement up to $259 \%$ than that of the plain tube by the insertion of turbulators. At the cost of increment in the friction factors, the enhancement of the Nusselt number is caused.But the enhancement in the friction factor is far greater than the Nusselt Number increament. the interaction of pressure forces with inertial forces in the boundary layer due to the secondary flows causes increament in the friction factor.The heat transfer rate for the DS arrangement enhanced up to $399 \%$, and for the CDS arrangement up to $299 \%$ and for the CS arrangement up to $199 \%$ than that of the plain tube by insertion of turbulators.

With the help of the experimental data in the test tube, the following empirical Nusselt number and friction factor relationships are derived for all the conical spring arrangements.

For the converging conical ring array :

$$
\begin{aligned}
& \mathrm{Nu}=0.2953 \times \operatorname{Re}^{0.609} \operatorname{Pr}^{0.4} \\
& \mathrm{f}=111.7205 \times \mathrm{Re}^{-0.536}
\end{aligned}
$$

For the convergent divergent conical arrangement :

$$
\begin{aligned}
& \mathrm{Nu}=0.3028 \times \operatorname{Re}^{0.65} \operatorname{Pr}^{0.4} \\
& \mathrm{f}=108.2020 \times \operatorname{Re}^{-0.518}
\end{aligned}
$$

For the divergent conical arrangement :

$$
\begin{aligned}
& \mathrm{Nu}=0.3080 \times \operatorname{Re}^{0.686} \operatorname{Pr}^{0.4} \\
& \mathrm{f}==87.6192 \times \operatorname{Re}^{-0.475}
\end{aligned}
$$

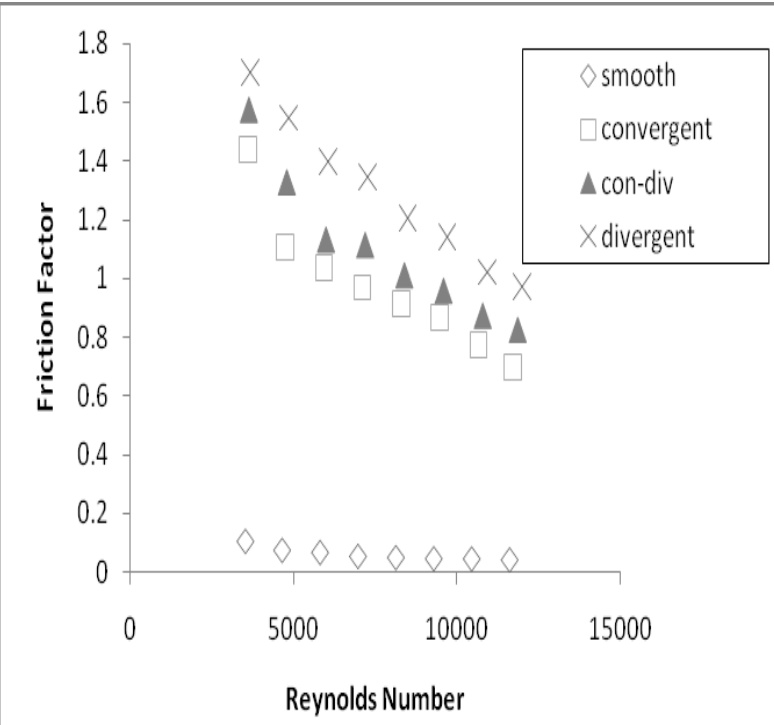

Fig 9 Variation of friction factor with Reynolds number for various turbulators.

\subsection{Performance Evaluation}

On the basis of power consumption per unit mass of fluid the heat transfer enhancement efficiency $(\eta)$ can be evaluated. The ratio of the heat transfer coefficient for the tube fitted with conical spring insert $\left(\mathrm{h}_{\mathrm{t}}\right)$ to that for the plain tube $\left(h_{p}\right)$ at a similar pumping power can be defined as the heat transfer enhancement efficiency. Following Ref. [10], the phenomenon can be defined as:

$$
\left(\mathrm{f} * \operatorname{Re}^{3}\right)_{\mathrm{p}}=\left(\mathrm{f} * \mathrm{Re}^{3}\right)_{\mathrm{t}}
$$

The heat transfer enhancement efficiency $(\eta)$ at a constant pumping power can be written as follows:

$$
\eta=\left(h_{t} / h_{p}\right)_{p p}
$$

Using Equations (17), (19), (21), (23) and (24), the Reynolds number for the plain tube $\left(\mathrm{R}_{\mathrm{p}}\right)$ can be written as a function of the Reynolds number for the conical sping insert $\left(\mathrm{Re}_{\mathrm{t}}\right)$ :

For the convergent conical spring insert

$$
\begin{aligned}
& 56.5995 \times \operatorname{Re}^{-0.780} \times \operatorname{Re}_{\mathrm{p}}^{3}=111.7205 \times \mathrm{Re}^{-0.536} \times \operatorname{Re}_{\mathrm{t}}^{3} \\
& \operatorname{Re}_{\mathrm{p}}{ }^{2.22}=1.9739 \times \operatorname{Re}_{\mathrm{t}}^{2.464} \\
& \operatorname{Re}_{\mathrm{p}}=1.3584 \times \operatorname{Re}_{\mathrm{t}}^{1.1099}
\end{aligned}
$$

For the convergent-divergent conical spring insert

$$
\begin{aligned}
& 56.5995 \times \operatorname{Re}_{\mathrm{p}}^{-0.780} \times \operatorname{Re}_{\mathrm{p}}^{3}=108.2020 \times \operatorname{Re}^{-0.518} \times \operatorname{Re}_{\mathrm{t}}^{3} \\
& \operatorname{Re}_{\mathrm{p}}{ }^{2.22}=1.9117 \times \operatorname{Re}_{\mathrm{t}}^{2.482} \\
& \operatorname{Re}_{\mathrm{p}}=1.3390 \times \operatorname{Re}_{\mathrm{t}}^{1.1180}
\end{aligned}
$$


For the divergent conical spring insert

$56.5995 \times \operatorname{Re}_{\mathrm{p}}^{-0.780} \times \operatorname{Re}_{\mathrm{p}}^{3}=87.6192 \times \operatorname{Re}^{-0.475} \times \operatorname{Re}_{\mathrm{t}}^{3}$

$\operatorname{Re}_{\mathrm{p}}^{2.22}=1.5481 \times \operatorname{Re}_{\mathrm{t}}^{2.525}$

$\operatorname{Re}_{\mathrm{p}}=1.2176 \times \operatorname{Re}_{\mathrm{t}}^{1.1374}$

Thus, the Reynolds number for the plain tube $\left(\mathrm{R}_{\mathrm{p}}\right)$ can be written as

$\operatorname{Re}_{\mathrm{p}}=1.3584 \times \operatorname{Re}_{\mathrm{t}}^{1.1099}$

$\operatorname{Re}_{\mathrm{p}}=1.3390 \times \operatorname{Re}_{\mathrm{t}}^{1.1180}$

$\operatorname{Re}_{\mathrm{p}}=1.2176 \times \operatorname{Re}_{\mathrm{t}}^{1.1374}$

Employing Equations (16), (18), (20), (22), (25), (26), (27) and (28), the enhancement efficiency for conical spring turbulators can be written as

For the convergent conical spring insert arrangement

$$
\begin{gathered}
\eta_{\text {convergent }}=\left(\mathrm{h}_{\mathrm{t}} / \mathrm{h}_{\mathrm{p}}\right)_{\mathrm{pp}} \\
\eta_{\text {convergent }}=\frac{0.2953 \times \mathrm{Re}_{\mathrm{t}}^{0.609} \times \operatorname{Pr}^{0.4}}{0.0520 \times \mathrm{Re}_{\mathrm{p}}^{0.60} \times \operatorname{Pr}^{0.4}} \\
\eta_{\text {convergent }}=\frac{0.2953 \times \mathrm{Re}_{\mathrm{t}}^{0.609} \times \operatorname{Pr}^{0.4}}{0.0520 \times 1.2278 \times \mathrm{Re}_{\mathrm{t}}^{0.7430} \times \operatorname{Pr}^{0.4}} \\
\eta_{\text {convergent }}=4.6252 \times \mathrm{Re}_{\mathrm{t}}^{-0.1346}
\end{gathered}
$$

For the convergent-divergent conical spring insert arrangement

$$
\begin{gathered}
\eta_{\text {convergent-divergent }}=\left(\mathrm{h}_{\mathrm{t}} / \mathrm{h}_{\mathrm{p}}\right)_{\mathrm{pp}} \\
\eta_{\text {convergent-diveregent }}=\frac{0.3028 \times \operatorname{Re}_{\mathrm{t}}^{0.65} \times \operatorname{Pr}^{0.4}}{0.0520 \times \operatorname{Re}_{\mathrm{p}}^{0.0 /} \times \operatorname{Pr}^{0.4}} \\
\eta_{\text {convergent-divergent }}=\frac{0.3028 \times \operatorname{Re}_{\mathrm{t}}^{0.609} \times \operatorname{Pr}^{0.4}}{0.0520 \times 1.2160 \times \operatorname{Re}_{\mathrm{t}}^{0.1491} \times \operatorname{Pr}^{0.4}} \\
\eta_{\text {convergent-divergent }}=4.7887 \times \operatorname{Re}_{\mathrm{t}}^{-0.0991}
\end{gathered}
$$

For the divergent conical spring insert arrangement

$$
\begin{gathered}
\eta_{\text {divergent }}=\left(\mathrm{h}_{\mathrm{t}} / \mathrm{h}_{\mathrm{p}}\right)_{\mathrm{pp}} \\
\eta_{\text {divergent }} \frac{=0.3080 \times \mathrm{Re}_{\mathrm{t}}^{0.686} \times \operatorname{Pr}^{0.4}}{0.0520 \times \mathrm{Re}_{\mathrm{p}}^{0.07} \times \operatorname{Pr}^{0.4}} \\
\eta_{\text {divergent }}=\frac{0.3080 \times \operatorname{Re}_{\mathrm{t}}^{0.686} \times \operatorname{Pr}^{0.4}}{0.0520 \times 1.1410 \times \operatorname{Re}_{\mathrm{t}}^{0.7621} \times \operatorname{Pr}^{0.4}} \\
\eta_{\text {divergent }}=5.1911 \times \operatorname{Re}_{\mathrm{t}}^{-0.0761}
\end{gathered}
$$

Thus the enhancement efficiency for all the conical spring array arrangement can be written as

$$
\begin{array}{ll}
\eta_{\text {convergent }} & =4.6252 \times \mathrm{Re}_{\mathrm{t}}^{-0.1346} \\
\eta_{\text {convergent-divergent }} & =4.7887 \times \mathrm{Re}_{\mathrm{t}}^{-0.0991} \\
\eta_{\text {divergent }} & =5.1911 \times \mathrm{Re}_{\mathrm{t}}^{-0.0761}
\end{array}
$$

Table 1 Heat transfer enhancement efficiency for various turbulators at different flow rate

\begin{tabular}{|l|l|l|l|l|}
\hline $\begin{array}{l}\text { Sr. } \\
\text { No }\end{array}$ & $\begin{array}{l}\text { Flow } \\
\text { rate of } \\
\text { water } \\
(\text { LPM })\end{array}$ & $\begin{array}{l}\eta \text { of } \\
\text { convergent } \\
\text { conical } \\
\text { spring } \\
\text { insert } \\
\left(\eta_{\text {convergent }}\right)\end{array}$ & $\begin{array}{l}\begin{array}{l}\eta \text { of } \\
\text { convergent- } \\
\text { divergent } \\
\text { conical } \\
\text { spring insert } \\
\left(\eta_{\text {convergent- }}\right.\end{array} \\
\begin{array}{l}\text { divergent } \\
\text { divergent } \\
\text { conical } \\
\text { spring } \\
\text { insert } \\
\left(\eta_{\text {divergent }}\right)\end{array}\end{array}$ \\
\hline 1. & 3 & 153.64 & 212.50 & 277.92 \\
\hline 2. & 4 & 148.02 & 206.75 & 272.13 \\
\hline 3. & 5 & 143.64 & 202.23 & 267.55 \\
\hline 4. & 6 & 140.16 & 198.61 & 263.87 \\
\hline 5. & 7 & 137.28 & 195.60 & 260.79 \\
\hline 6. & 8 & 134.84 & 193.03 & 258.15 \\
\hline 7. & 9 & 132.72 & 190.79 & 255.85 \\
\hline 8. & 10 & 131.04 & 189.01 & 254.02 \\
\hline
\end{tabular}

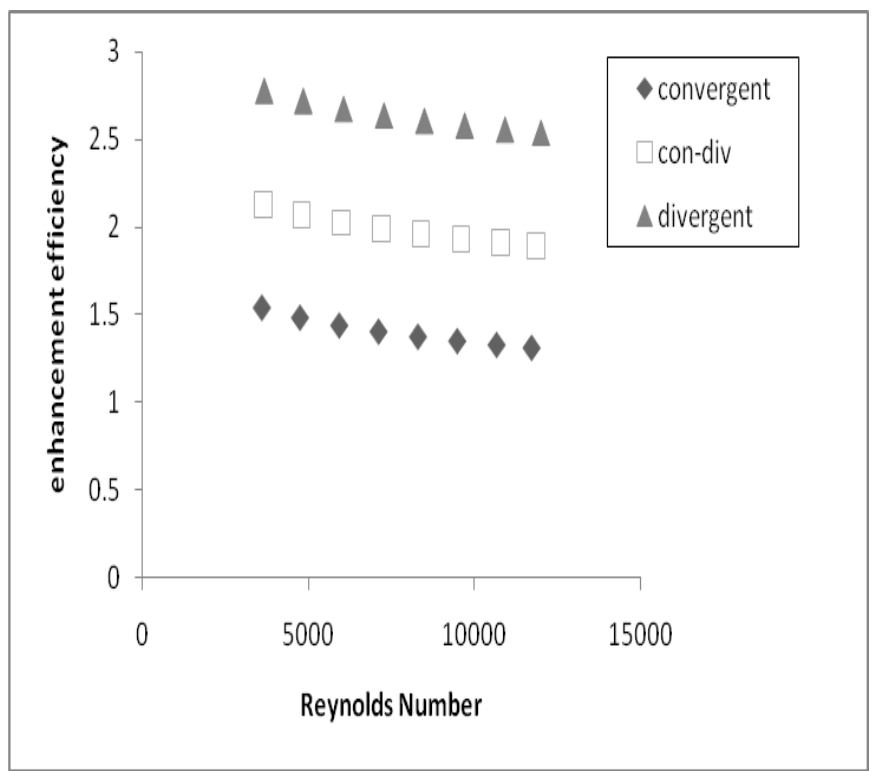

Fig 10 Variation of enhancement efficiency with Reynolds number forvarious turbulators.

\section{CONCLUSION}

The experimental investigation of heat transfer enhancement and friction factor analysis in a circular tube with conical spring inserts is done and has following conclusions

- $\quad$ The experimental results of the plain tube are found to be in good agreement with theoretical correlations of Gnielinski and Petukhov. 
- Nusselt Number for the divergent conical spring array arrangement enhanced up to $645 \%$, and for the convergent-divergent conical spring array arrangement up to $431 \%$ and for the conical spring array arrangement up to $259 \%$ than that of the plain tube by the insertion of turbulators.

- The enhancement in the Friction Factor is far greater than the Nusselt Number enhancement.

- The heat transfer (Q) for the divergent conical spring array arrangement enhanced up to $399 \%$, and for the convergent-divergent conical spring array arrangement up to $299 \%$ and for the convergent conical spring array arrangement up to $199 \%$ than that of the plain tube by insertion of turbulators.

- Heat transfer Enhancement Efficiencies ( $\eta$ ) were found for the divergent conical spring array arrangement up to $277 \%$ and for the convergentdivergent conical spring array arrangement up to $212 \%$ and for the convergent conical spring array arrangement up to $153 \%$.

\section{REFERENCES}

[1] Bodius Salam, Sumana Biswas, Shuvra Saha, Muhammad Mostafa K Bhuiya, "Heat transfer enhancement in a tube using rectangular-cut twisted tape insert", $5^{\text {th }}$ BSME International Conference on Thermal Engineering, Procedia Engineering 56 (2013); $96-103$.

[2] P. Promvonge, "Heat transfer behaviors in round tube with conical ring inserts", Energy Conversion and Management 49 (2008) 8-15.

[3] Aydın Durmus, "Heat transfer and exergy loss in cut out conical turbulators", Energy Conversion and Management 45 (2004) 785-796.

[4] Pongjet Promvonge, Smith Eiamsa-ard, "Heat transfer and turbulent flow friction in a circular tube fitted with conical-nozzle turbulators", International Communications in Heat and Mass Transfer 34 (2007) 72-82.

[5] P. Promvonge, S. Eiamsa-ard, "Heat transfer enhancement in a tube with combined conical-nozzle inserts and swirl generator", Energy Conversion and Management 47 (2006) 2867-2882.

[6] Anvari AR, Lotfi R, Rashidi AM, Sattari S, "Experimental research on heat transfer of water in tubes with conical ring inserts in transient regime". Int Commun Heat Mass Transfer 2011;38:668-71.

[7] A.R. Anvari , K. Javaherdeh, M. Emami-Meibodi , A.M. Rashidi, "Numerical and experimental investigation of heat transfer behavior in a round tube with the special conical ring inserts" Energy Conversion and Management 88 (2014); 214-217.

[8] P. Bharadwaj, A.D. Khondge, A.W. Date, "Heat transfer and pressure drop in a spirally grooved tube with twisted tape insert", International Journal of Heat and Mass Transfer 52 (2009) 1938-1944.
[9] Haydar Eren, "Exergy Analysis of Coil-Spring Turbulators Inserted in the Horizontal Concentric Tubes" Journal of Heat Transfer October 2010; Vol. 132 / 101802-1.

[10] Kenan Yakut, Bayram Sahin, Suat Canbazoglu, "Performance and flow-induced vibration characteristics for conical-ring turbulators", Applied Energy 79 (2004) 65-76.

[11] Kenan Yakut, Bayram Sahin, "Flow-induced vibration analysis of conical rings used for heat transfer enhancement n heat exchangers", Applied Energy 78 (2004) 273-288

[12] Incropera F, Dewitt PD, "Introduction to heat transfer", third ed. John Wiley and Sons Inc.; 1996.

\section{BIOGRAPHIES}

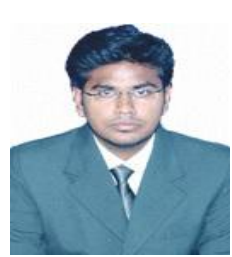

Rahul M. Gupta, M. Tech. Research Scholar, Department of Mechanical Engg, Shri Ramdeobaba College of Engg, And Management, Nagpur, rahulgupta0290@gmail.com

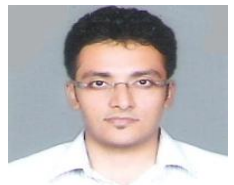

Bhushan C. Bissa, Assistant Professor , Department of Mechanical Engg, Shri Ramdeobaba college of Engg., and Management,Nagpur, bissabc@rknec.edu 